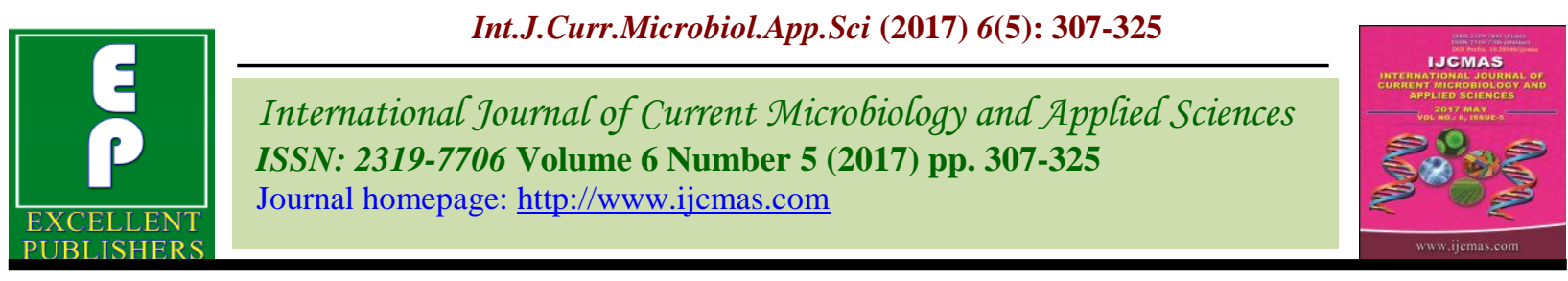

Original Research Article

https://doi.org/10.20546/ijcmas.2017.605.035

\title{
Optimization of Culture Conditions Using One-Factor-at-Time Methodology and Partial Purification of Amylase from Aspergillus niger of DTO: H5 under Solid State Fermentation
}

\author{
F.S. Ire*, O.C. Eruteya and V. Amaechi \\ Department of Microbiology, University of Port Harcourt, Port Harcourt, Nigeria \\ *Corresponding author
}

\begin{tabular}{|c|c|}
\hline & A B S T R A C T \\
\hline & \multirow{5}{*}{$\begin{array}{l}\text { The aim of this study was to isolate amylase-producing fungi, optimize the cultural } \\
\text { conditions using solid state fermentation (SSF) and characterize the partially purified } \\
\text { enzyme. Six fungal strains isolated from soil and decayed onion samples were screened for } \\
\text { their ability to secrete amylase. Culture medium was optimized using One-factor-at-a- } \\
\text { Time (OFAT) methodology under SSF. The crude enzyme was partially purified by } \\
\text { ammonium sulphate precipitation and the effect of physicochemical parameters on the } \\
\text { amylase was investigated. Out of the six fungal strains, isolate } \mathrm{F} 3 \text { showed highest amylase } \\
\text { producing ability. Phylogenetic analysis based on partial sequence of the } 18 \mathrm{~S} \text { rRNA gene } \\
\text { classified } \mathrm{F} 3 \text { as Aspergillus niger DTO: H5. Maximum amylase production was achieved } \\
\text { within } 48 \mathrm{~h} \text { of cultivation using } 5 \%(\mathrm{w} / \mathrm{v}) \text { wheat bran. Optimal SSF conditions which } \\
\text { favoured amylase production were: fermentation period } 48 \mathrm{~h} \text {, initial pH } 6.0 \text {, initial } \\
\text { temperature } 30^{\circ} \mathrm{C} \text {, substrate to moisture content ratio } 1: 5 \text { and inoculum size } 1.3 \times 10^{10} \\
\text { spores/ml. Crude amylase was partially purified by } 80 \% \text { ammonium sulphate saturation. } \\
\text { The enzyme was purified } 3.77-\text { fold with specific activity of } 36.65 \mathrm{U} / \mathrm{mg} \text { and percentage } \\
\text { yield of } 90.53 \% \text {. Optimum enzyme activity was noticed at } 50^{\circ} \mathrm{C} \text { and } \mathrm{pH} 4.0 \text {. Ca }{ }^{2+} \text { had the } \\
\text { highest stimulatory effect while } \mathrm{Hg}^{2+} \text { significantly (p< } 0.05 \text { ) inhibited the enzyme activity. } \\
\text { Presence of } \mathrm{Mg}^{2+}, \mathrm{Na}^{+} \text {and Fe } \mathrm{Fe}^{2+} \text { increased the amylase activity while Cu } \mathrm{Cu}^{2+} \text { and } \mathrm{Zn}^{2+} \text { were } \\
\text { slightly inhibitory. This study showed that the fungus could utilize cost effective substrates } \\
\text { (wheat bran) for amylase production and could be a promising source of the enzyme for } \\
\text { allied and biotechnological industries. }\end{array}$} \\
\hline $\begin{array}{l}\text { Ke y w o r d s } \\
\text { Aspergillus niger, } \\
\text { Production, } \\
\text { Amylase, Wheat } \\
\text { bran, Optimization, } \\
\text { Characterization. }\end{array}$ & \\
\hline Article Info & \\
\hline $\begin{array}{l}\text { Accepte } \\
\text { 04 Apri } \\
\text { Availab } \\
10 \text { May }\end{array}$ & \\
\hline & \\
\hline
\end{tabular}

\section{Introduction}

Amylases are of ubiquitous occurrence and hold the maximum market share of enzyme sales as they account for about $30 \%$ of the world's enzyme production (Van der Maarel et al., 2002). Amylases are one the most important industrial enzymes that have a wide variety of applications ranging from conversion of starch to sugar syrups, production of cyclodextrins for the pharmaceutical industry, detergent production, fermentation, brewing and textile to paper industries (Kathiresan and Manivannan, 2006). In order to meet the high demands of these industries, there is therefore need for low cost production of amylase.

Amylase is universally distributed throughout animals, plants and microbial kingdoms. However, due to efficient production strategies, microorganisms have substantial 
potential to contribute to a number of industrial applications (Sodhi et al., 2005). Fungal enzymes are more preferable to enzymes from other microorganisms because of their Generally Regarded as Safe (GRAS) status (Sindhu et al., 2009). Studies on fungal amylase especially in the developing countries have concentrated mainly on Aspergillus species probably because of ubiquitous nature and non-fastidious nutritional requirement of this organism (Abu et al., 2005; Gomes et al., 2005; Okolo et al., 2000).

Amylases are industrially produced by microorganisms either by submerged fermentation (SmF) or solid-state fermentation (SSF). SSF processes present numerous advantages over $\mathrm{SmF}$. The former not only requires a lower volume of liquid for product recovery and a cheap medium for fermentation, it also poses lower risk of contamination on account of unavailability of free flowing substrates. Enzymes produced by SSF have been reported to possess more stable properties and are less affected by catabolic repression than enzymes produced by SmF (Acuna et al., 1995). However, the contents of a synthetic medium are very expensive and uneconomical, so they need to be replaced with more economically available agricultural and industrial by-products, as they are considered to be good substrates for $\mathrm{SSF}$ to produce enzymes (Kunamneni et al., 2005).

Agro-industrial residues pose serious problems of disposal, in spite of them being sources of biomass and nutrients. They are generally considered the best substrates for SSF processes and have been reported to be good substrates for the cost effective production of amylases (Kirankumar et al., 2011). Hence, the present study was aimed to accomplish the objective of production of amylase from various agricultural by-products by Aspergillus niger using solid state fermentation technique, the determination of optimized production conditions and the partial purification and characterization of the amylase produced.

\section{Materials and Methods}

\section{Fungi isolation from soil and decayed} onion samples

Fungi were isolated from soil and decayed onion samples by serial dilution method wherein Potato Dextrose Agar (PDA) media was prepared, autoclaved and poured in sterile petri-dishes. A $0.1 \mathrm{ml}$ from various dilutions $\left(10^{-1}-10^{-5}\right)$ of both samples were plated in duplicate on respective PDA agar (containing $10 \%$ lactic acid to prevent bacteria growth) which had solidified. After inoculation the petri-dishes were put in the incubator at $28 \pm$ $2^{\circ} \mathrm{C}$ for $48 \mathrm{~h}$. Their different physical characteristics were used to differentiate the isolated fungi after which they were named properly. The isolates were sub cultured by point inoculation on sterile PDA plates containing lactic acid and incubation was done at $28 \pm 2{ }^{\circ} \mathrm{C}$ for $48 \mathrm{~h}$ so as to get pure fungal isolates.

\section{Screening of fungal isolates for amylase production}

The ability of the isolates to produce amylase was studied using starch agar media containing the following (gram/litre): yeast extract 1.5, starch 10, peptone 0.5, agar 15, Sodium chloride 1.5, at $\mathrm{pH}$ 5.6. The isolates were inoculated on the starch agar media by streaking after which incubation was done at $28 \pm 2^{\circ} \mathrm{C}$ for a period of $48 \mathrm{~h}$. A control having no inoculation was set up for comparison. All the plates including the control were flooded with iodine solution after incubation and the zone of hydrolysis was observed (Jahir and Sachin, 2011). 
Identification of the highest amylase producer

The best amylase producer was identified according to its physical/macroscopic features, microscopic characteristics (Lactophenol cotton blue) and molecular characteristics (Aneja, 2003).

Procurement of cheap substrates and their preparation

The cheap substrates used are wheat bran, rice husk, cassava peels and groundnut husk. The substrates were gotten from Oshodi market dump sites in Lagos and agro waste reserve of Federal Institute of Industrial research Oshodi, Lagos. The substrates were prepared by washing, them severally with distilled water, drying them and grinding them using a sterile blender.

\section{Mineral media for enzyme production}

The following are the compositions of the mineral media used for enzyme production; Soluble starch $(5 \mathrm{~g} / \mathrm{l})$, Yeast extract $(2 \mathrm{~g} / \mathrm{l})$, Potassium dihydrogen phosphate $(1 \mathrm{~g} / \mathrm{l})$, Magnesium sulphate $(0.5 \mathrm{~g} / \mathrm{l}), \quad$ Calcium chloride $(0.1 \mathrm{~g} / \mathrm{l})$, Sodium chloride $(0.8 \mathrm{~g} / \mathrm{l})$. All of the above were dissolved in $1000 \mathrm{ml}$ of distilled water after which the preparation was autoclaved.

\section{Preparation of inoculum}

Inoculum preparation was done according to the method described by Pandey (1992). Spores from $48 \mathrm{~h}$ old slant cultures were used for the inoculation. Spore suspension of the isolate was prepared by pouring ten milliliters $(10 \mathrm{ml})$ of sterile distilled water containing two drops of $0.1 \%$ Tween 80 to the surface of the slant having copious spore growth. A sterile inoculating needle was used to scrape the spore clumps under aseptic conditions after which the tube was vigorously shaken to homogenize the suspension.

\section{Production of enzyme by solid state} fermentation

Five grams $(5 \mathrm{~g})$ of each substrate i.e. wheat bran, rice husk, cassava peel and groundnut husk was transferred into individual Erlenmeyer flasks $(250 \mathrm{ml})$ with five milliliters $(5 \mathrm{ml})$ of mineral medium $(\mathrm{pH} 7)$ i.e. substrate-medium ratio of $1: 1$. The flasks containing the substrates and the mineral medium were autoclaved and allowed to cool after which they were inoculated with one milliliter $(1 \mathrm{ml})$ of $48 \mathrm{~h}$ old grown spore suspension of the isolate which gave highest hydrolysis. Incubation was done at $28 \pm 2^{\circ} \mathrm{C}$ under static conditions. All fermentation setups were performed in triplicates. Crude enzymes were extracted after incubation and assayed for their activities. The data represents the mean of three determinations.

\section{Enzyme extraction}

After fermentation, the crude enzyme was extracted by shaking the substrate with $0.2 \mathrm{M}$ Phosphate buffer for $30 \mathrm{~min}$ in a rotary shaker (250rpm) at a ratio of 1:5 (solid to moistening agent). Filtration of the extract was done using Whatman No.1 filter paper so as to get a clear filtrate which was centrifuged for 20 $\mathrm{min}$ at 5000rpm. The supernatant was filtered using Whatman No.1 filter paper to get a cell free supernatant which is the crude enzyme (Kheng and Omar 2005).

\section{Determination of protein concentration in crude enzyme}

Proteins in the enzyme preparations were determined by the method of Lowry et al., (1951) with bovine serum albumin as standard. 


\section{Assay of enzyme}

Determination of amylase activity was done using the method of Miller (1959). Amylase was measured by incubating $1 \%$ of soluble starch in $0.2 \mathrm{M}$ Phosphate buffer of $\mathrm{pH} 7.0$ at $45^{\circ} \mathrm{C}$ for $30 \mathrm{~min}$. The enzyme was assayed by using one milliliter $(1 \mathrm{ml})$ of crude enzyme solution and adding one milliliter $(1 \mathrm{ml})$ of substrate-buffer solution. This mixture was placed in an incubator at $45^{\circ} \mathrm{C}$ for $30 \mathrm{~min}$ after which the enzyme reaction was stopped by adding two milliliters (2ml) of Dinitrosalicyclic acid (DNS) reagent. One milliliter of the substrate-buffer solution added to one milliliter $(1 \mathrm{ml})$ of distilled water was used as reference blank. All the tubes containing DNS reagent treated reaction products were heated for $15 \mathrm{~min}$ in boiling water bath for colour development. The final volume in each case was made to ten milliliters $(10 \mathrm{ml})$ by adding distilled water after cooling. Absorbance was read at $540 \mathrm{~nm}$ using UV-Visible spectrophotometer and compared with standard curve using 0.1 to 1.0 milligram (mg) of glucose/ml. One unit (U) of enzyme activity was expressed as the quantity of enzyme required to release one micromole $(\mu \mathrm{mol})$ of glucose per minute per milliliter (ml) under standard assay conditions by using glucose standard curve (Behera et al., 2014).

\section{Production studies}

\section{Screening of substrates for amylase production}

The impact of the substrates on amylase production were carried out by inoculating five grams $(5 \mathrm{~g})$ of each substrate containing five milliliters $(5 \mathrm{ml})$ of mineral medium $(\mathrm{pH}$ 7) with one milliliter of spore suspension of the organism and incubating at $28 \pm 2{ }^{\circ} \mathrm{C}$ for a period of five (5) days (Puri et al., 2013) while other parameters were kept constant.

\section{Effect of incubation period on amylase production}

Flasks containing five grams $(5 \mathrm{~g})$ of the substrate were fermented under pre-optimized growth conditions with one milliliter $(1 \mathrm{ml})$ of spore suspension and five milliliters $(5 \mathrm{ml})$ of mineral medium (ratio 1:1) of $\mathrm{pH} 7$ and incubated at $28 \pm 2^{\circ} \mathrm{C}$ in rotary shaker. The enzyme was extracted and assayed from $0 \mathrm{~h}$ to the $8^{\text {th }}$ day.

\section{Effect of initial moisture on amylase production}

The effect of the moisture content on amylase production was tested by varying the substrate to mineral medium ratio $(\mathrm{w} / \mathrm{v})$ in ranges of $1: 1,1: 2,1: 3,1: 4$ and 1:5. Inoculation of the flasks which contained five grams $(5 \mathrm{~g})$ of the substrate and $5 \mathrm{ml}, 10 \mathrm{ml}, 15 \mathrm{ml}, 20 \mathrm{ml}$ and $25 \mathrm{ml}$ of mineral medium, respectively was done with one milliliter $(1 \mathrm{ml})$ of spore suspension of the organism. The flasks were incubated for $48 \mathrm{~h}$ at $28 \pm 2{ }^{\circ} \mathrm{C}$. Moisture was provided by the medium itself at $\mathrm{pH}$ 7.0.

\section{Effect of initial pH on amylase production}

The study of the effect of initial $\mathrm{pH}$ on amylase production was carried out by varying the mineral medium $\mathrm{pH}$ to $3.0,4.0$, $5.0,6.0$ and 7.0. Inoculation of the flasks containing five grams $(5 \mathrm{~g})$ of the substrate and optimum amount of sterile mineral medium (at various $\mathrm{pH}, 83.3 \%$ ) was done using one milliliters $(1 \mathrm{ml})$ of spore suspension of the organism. Incubation was done for $48 \mathrm{~h}$ at $28 \pm 2^{\circ} \mathrm{C}$.

\section{Effect of temperature on amylase production}

The effect of temperature on amylase production was examined by incubating the inoculated flasks containing a mixture of five 
grams $(5 \mathrm{~g})$ of the substrate with optimized quantity of mineral medium $(83.3 \%)$ having the optimized $\mathrm{pH}$ at various temperature ranges of $20^{\circ} \mathrm{C}-40^{\circ} \mathrm{C}$ for $48 \mathrm{~h}$.

\section{Effect of inoculum concentration on amylase production}

The effect of the inoculum concentration (based on the number of spores $/ \mathrm{ml}$ ) on amylase production was studied by inoculating the substrate with different inoculum levels from the dilutions $10^{-5}, 10^{-6}$, $10^{-7}$ and $10^{-8}$ respectively. SSF was carried out for $48 \mathrm{~h}$ with $83.3 \%$ moisture and incubated at $30^{\circ} \mathrm{C}$.

The determination of the inoculum size was done by counting the number of cells per milliliter using serial dilution and plating techniques. One milliliter $(1 \mathrm{ml})$ from $48 \mathrm{~h}$ old grown culture was taken, serially diluted $\left(10^{-}\right.$ $1-10^{-8}$ ) and $0.1 \mathrm{ml}$ from the dilutions $10^{-5}-10^{-8}$ were spread aseptically on PDA agar. The number of spores for each dilution plated was counted and thereafter multiplied by the dilution factor.

\section{Time course study}

A time course study was carried out on amylase production using the optimized fermentation parameters. Flasks containing five grams $(5 \mathrm{~g})$ of the substrate (wheat bran) and twenty five milliliters $(25 \mathrm{ml})$ of the mineral medium having $\mathrm{pH} 6$ were inoculated with one milliliter $(1 \mathrm{ml})$ of spore suspension of the organism containing $1.30 \times 10^{10}$ spores $/ \mathrm{ml}$ and incubated for varying periods of time (1-6 days) at $30^{\circ} \mathrm{C}$.

One flask was withdrawn each day for the period of six (6) days and the crude enzyme was extracted using $0.2 \mathrm{M}$ phosphate buffer after which amylase activity was determined using DNS method as earlier described.

\section{Partial purification of amylase}

Crude amylase produced from the time course study after a period of two days was purified with ammonium sulphate. Crude amylase (10ml) was concentrated with different concentrations of ammonium sulphate i.e. $60 \%, 70 \%$ and $80 \%$ saturations $(6 \mathrm{~g} / 10 \mathrm{ml}$, $7 \mathrm{~g} / 10 \mathrm{ml}$ and $8 \mathrm{~g} / 10 \mathrm{ml}$ respectively). The mixture was chilled at $4{ }^{\circ} \mathrm{C}$ in a refrigerator overnight to prevent denaturation after which the precipitate was separated by centrifugation at $10,000 \mathrm{rpm}$ for $15 \mathrm{~min}$ and the residue dissolved with $0.2 \mathrm{M}$ Phosphate buffer of $\mathrm{pH} 7.0$ in order to obtain the partially purified enzyme, which was assayed for its activity.

\section{Effect of $\mathrm{pH}$ on partially purified amylase activity}

The enzyme activity was assayed over a $\mathrm{pH}$ range of 3.0-10.0 using $0.2 \mathrm{M}$ phosphate buffer. The buffer solution was used to prepare the $1 \%$ soluble starch solution used as substrate in assaying the enzyme activity. The assay was done in duplicates for each $\mathrm{pH}$ using standard assay procedure. The control blank was set up using one milliliter $(1 \mathrm{ml})$ of substrate-buffer solution and one milliliter $(1 \mathrm{ml})$ of distilled water under standard assay conditions ( $\mathrm{pH} 7.0$, temperature $-45^{\circ} \mathrm{C}$ ).

\section{Effect of temperature partially purified amylase activity}

The enzyme activity was assayed at different temperatures $\left(30^{\circ} \mathrm{C}-70^{\circ} \mathrm{C}\right)$. The buffer solution of $\mathrm{pH} 4.0$ was used to prepare the $1 \%$ soluble starch solution used as substrate in assaying the enzyme activity. The assay was done in duplicates for each temperature using standard assay procedure. The control blank was set up using $1 \mathrm{ml}$ of substrate-buffer solution and one milliliter $(1 \mathrm{ml})$ of distilled water under standard assay conditions $(\mathrm{pH} 7$, temperature $-45^{\circ} \mathrm{C}$ ). 
Effect of metal ions on the partially purified amylase activity

The enzyme activity was determined in the presence of various ions at $10 \mathrm{~m} \mathrm{M}$ concentration. The ions studied were $\mathrm{Mg}^{2+}$, $\mathrm{Cu}^{2+}, \mathrm{Na}^{+}, \mathrm{Hg}^{2+}, \mathrm{Zn}^{2+}, \mathrm{Ca}^{2+}, \mathrm{Fe}^{2+}$. The buffer solution of $\mathrm{pH} 4$ was used to prepare the $1 \%$ soluble starch solution used as substrate in assaying the enzyme activity at temperature of $50^{\circ} \mathrm{C}$.

The assay was done in duplicates for each metal ion using standard assay procedure. The control was set up using one milliliter $(1 \mathrm{ml})$ of the enzyme and one milliliter $(1 \mathrm{ml})$ of the substrate-buffer solution $(\mathrm{pH} 4.0)$ while the blank was set up using $1 \mathrm{ml}$ of substrate-buffer solution and $1 \mathrm{ml}$ of distilled water under standard assay conditions $(\mathrm{pH} \mathrm{7,} \mathrm{temperature-}$ $\left.45^{\circ} \mathrm{C}\right)$.

\section{Results and Discussion}

Identification of the highest amylase producer

The best amylase producer strain was identified using conventional and molecular methods as Aspergillus niger DTO: 133-H5 with accession number KX786646.

Screening of substrates for amylase production

The result represented in table 1 shows that out of the four agricultural residues screened, wheat bran gave the highest amylase excretion $(305.26 \pm 0.00 \mathrm{U} / \mathrm{ml})$ followed by cassava peels $(114.45 \pm 0.16 \mathrm{U} / \mathrm{ml})$ with a relative enzyme yield of $37.49 \%$.

Rice bran gave the lowest amylase production $(36.14 \pm 0.33 \mathrm{U} / \mathrm{ml})$ with a relative enzyme yield of $11.84 \%$. Thus, wheat bran was selected as substrate for further study.
Effect of different cultural conditions on enzyme production

\section{Effect of incubation period on amylase production}

In figure 1, the effect of various periods of incubation $\left(0-8^{\text {th }}\right.$ day) on amylase production is shown. The results revealed that amylase production was highest after $48 \mathrm{~h}$ of incubation with $324.93 \pm 0.16 \mathrm{U} / \mathrm{ml}$ enzyme activity after which enzyme production decreased with increase in incubation period. Thus, incubation period of $48 \mathrm{~h}$ was optimum for amylase production.

\section{Effect of moisture content on amylase production}

The effect of moisture content on amylase production is shown in figure 2 . The results revealed that as moisture content increased, amylase production also increased. Maximum amylase production $(317.31 \pm 0.33 \mathrm{U} / \mathrm{ml})$ was observed when the moisture content was twenty five milliliters $(25 \mathrm{ml})$. Hence, twenty five milliliters $(25 \mathrm{ml})$ of the medium $/ 5 \mathrm{gram}$ of the substrate (1:5 ratio) was taken to be the optimum moisture level.

\section{Effect of initial pH on amylase production}

The impact of the initial $\mathrm{pH}$ on amylase production is depicted in figure 3. The synthesis of enzyme increased with increase in $\mathrm{pH}$. The result showed that enzyme production was highest at $\mathrm{pH} 6.0$ after which production decreased with further increase in $\mathrm{pH}$. $\mathrm{pH} 6.0$ was taken as the best for amylase production with activity $304.01 \pm 0.16 \mathrm{U} / \mathrm{ml}$.

\section{Effect of temperature on amylase production}

The effect of different temperatures of incubation on the production of amylase is 
presented in figure 4 . The results showed that Aspergillus niger DTO: 133-H5 (KX786646) yielded maximum amylase production of $319.47 \pm 0.16 \mathrm{U} / \mathrm{ml}$ at $30^{\circ} \mathrm{C}$. There was a decrease in amylase production at $20^{\circ} \mathrm{C}$ while further increase above $30^{\circ} \mathrm{C}$ led to reduction in amylase production.

Effect of inoculum concentration on amylase production

Figure 5 shows the impact of different concentrations of Aspergillus niger DTO: 133-H5 (KX786646) on the production of amylase. The results indicated that as the inoculum size decreased from $3.90 \times 10^{7}$ to $1.30 \times 10^{10}$ cells $/ \mathrm{ml}$, there was increase in amylase production from $200.48 \pm 0.32 \mathrm{U} / \mathrm{ml}$ to $284.69 \pm 0.16 \mathrm{U} / \mathrm{ml}$. Thus, inoculum size of $1.30 \times 10^{10}$ cells $/ \mathrm{ml}$ was optimum for amylase production.

Time course study of amylase production by Aspergillus niger DTO: 133-H5

The result for the time course study carried out on amylase production from wheat bran by Aspergillus niger DTO: 133-H5 (KX786646), using optimized fermentation parameters for a period of six (6) days is illustrated in table 2. The crude amylase extract had highest activity of $299.01 \pm 0.16$ $\mathrm{U} / \mathrm{ml}$ after $48 \mathrm{~h}$. This was partially purified using ammonium sulphate and used for further studies.

\section{Partial purification of amylase by} ammonium sulphate precipitation

As shown in table 3, of the various ammonium sulphate fraction used for the partial purification of amylase, $80 \%$ fraction gave the highest activity of $270.5 \pm 0.13 \mathrm{U} / \mathrm{ml}$ while $70 \%$ and $60 \%$ fractions gave activities of $258.29 \pm 0.38 \mathrm{U} / \mathrm{ml}$ and $232.02 \pm 0.17 \mathrm{U} / \mathrm{ml}$ respectively. The summary of partial purification of amylase using $80 \%$ ammonium sulphate saturation is shown in table 4 . The percentage yield from $80 \%$ fraction was $90.53 \%$ and the purification fold obtained was 3.77. Hence, characterization studies of amylase were done using this partially purified fraction.

Table 4 shows the purification summary of the partial purification of crude amylase using $80 \%$ ammonium sulphate concentration. The specific activity of the partially purified amylase was $36.65 \mathrm{U} / \mathrm{mg}$ with purification fold of 3.77 and percentage yield of $90.58 \%$.

\section{Effect of $\mathrm{pH}$ on partially purified amylase activity}

The impact of various $\mathrm{pH}$ from 3.0 to 10.0 on partially purified amylase $(80 \%$ concentration) is illustrated in figure 6 . From the observations, partially purified amylase had highest activity at $\mathrm{pH} 4.0$ and the relative enzyme activity was taken as $100 \%$. There was $2.52 \%$ decrease in activity as $\mathrm{pH}$ increased to 5.0 and $18.73 \%$ decrease in activity as $\mathrm{pH}$ increased to 6.0 . When the $\mathrm{pH}$ was reduced to 3.0 , there was a decrease in activity by $11.17 \%$.

\section{Effect of temperature on partially purified amylase activity}

Highest amylase activity was obtained at $50^{\circ} \mathrm{C}$ (Figure 7) when partially purified amylase preparation was incubated at different temperatures for a period of 30 minutes using the optimized $\mathrm{pH}$ (4.0).

At lower temperatures of $40^{\circ} \mathrm{C}$ and $30^{\circ} \mathrm{C}$, amylase activity decreased by $11.10 \%$ and $23.63 \%$ respectively while at higher temperatures of $60^{\circ} \mathrm{C}$ and $70^{\circ} \mathrm{C}$, amylase activity decreased by $5.55 \%$ and $36.88 \%$, respectively. 
Effect of metal ions on partially purified amylase activity

The effect of metal ions on partially purified amylase activity is shown in figure 8 . Result obtained indicate that amylase activity was stimulated by the presence of the metal ions; $\mathrm{Ca}^{2+}\left(230.88 \%\right.$ relative activity), $\mathrm{Mg}^{2+}$
(155.02\% relative activity), $\mathrm{Na}^{+}(141.76 \%$ relative activity) and $\mathrm{Fe}^{2+}(139.72 \%$ relative activity) while the presence of $\mathrm{Hg}^{2+}, \mathrm{Cu}^{2+}$ and $\mathrm{Zn}^{2+}$ ions inhibited amylase activity with mercury ion $\left(\mathrm{Hg}^{2+}\right)$ having the highest inhibitory effect and the least relative enzyme activity of $60.34 \%$.

Table.1 Screening of substrates for the production of amylase

\begin{tabular}{cccc}
\hline $\begin{array}{c}\text { Serial } \\
\text { No }\end{array}$ & Substrates & Amylase activity (U/ml) & Relative enzyme yield (\%) \\
\hline 1 & Wheat bran & $305.26 \pm 0.00$ & 100 \\
2 & Cassava peels & $114.45 \pm 0.16$ & 37.49 \\
3 & Groundnut husk & $101.61 \pm 0.32$ & 33.29 \\
4 & Rice bran & $36.14 \pm 0.33$ & 11.84 \\
\hline
\end{tabular}

Table.2 Time course study of amylase production by Aspergillus niger

\begin{tabular}{ccc}
\hline Serial No & Days & Activity $(\mathbf{U} / \mathbf{m l})$ \\
\hline 1 & 1 & $297.31 \pm 0.32$ \\
2 & 2 & $299.01 \pm 0.16$ \\
3 & 3 & $281.85 \pm 0.00$ \\
4 & 4 & $284.92 \pm 0.16$ \\
5 & 5 & $285.72 \pm 0.32$ \\
6 & 6 & $285.60 \pm 0.48$ \\
\hline
\end{tabular}

Table.3 Partial purification of amylase using various fractions of ammonium sulphate

\begin{tabular}{cc}
\hline Fraction & Amylase activity (U/ml) \\
\hline $60 \%$ ammonium sulphate saturation & $232.02 \pm 0.17$ \\
$70 \%$ ammonium sulphate saturation & $258.29 \pm 0.38$ \\
$80 \%$ ammonium sulphate saturation & $270.5 \pm 0.13$ \\
\hline
\end{tabular}


Table.4 Summary of partial purification of amylase using $80 \%$ ammonium sulphate saturation

\begin{tabular}{lllllllll}
\hline Fraction & $\begin{array}{l}\text { Enzyme } \\
\text { Vol } \\
(\mathbf{m l})\end{array}$ & $\begin{array}{l}\text { Protein } \\
\text { Conc. } \\
(\mathbf{m g} / \mathbf{m l})\end{array}$ & $\begin{array}{l}\text { Amylase } \\
\text { activity } \\
(\mathbf{U} / \mathbf{m l})\end{array}$ & $\begin{array}{l}\text { Total } \\
\text { protein } \\
(\mathbf{m g})\end{array}$ & $\begin{array}{l}\text { Total } \\
\text { activity } \\
\text { (Units) }\end{array}$ & $\begin{array}{l}\text { Specific } \\
\text { activity } \\
(\mathbf{U} / \mathbf{m g})\end{array}$ & $\begin{array}{l}\text { Purification } \\
\text { fold }\end{array}$ & $\begin{array}{l}\text { \% } \\
\text { yield }\end{array}$ \\
\hline $\begin{array}{l}\text { Crude } \\
\text { extract }\end{array}$ & 1 & 30.77 & 298.81 & 30.77 & 298.81 & 9.71 & 1 & 100 \\
$\begin{array}{l}\text { Ammonium } \\
\text { sulphate }\end{array}$ & 10 & 7.38 & 270.5 & 73.8 & 2705 & 36.65 & 3.77 & 90.53 \\
\hline
\end{tabular}

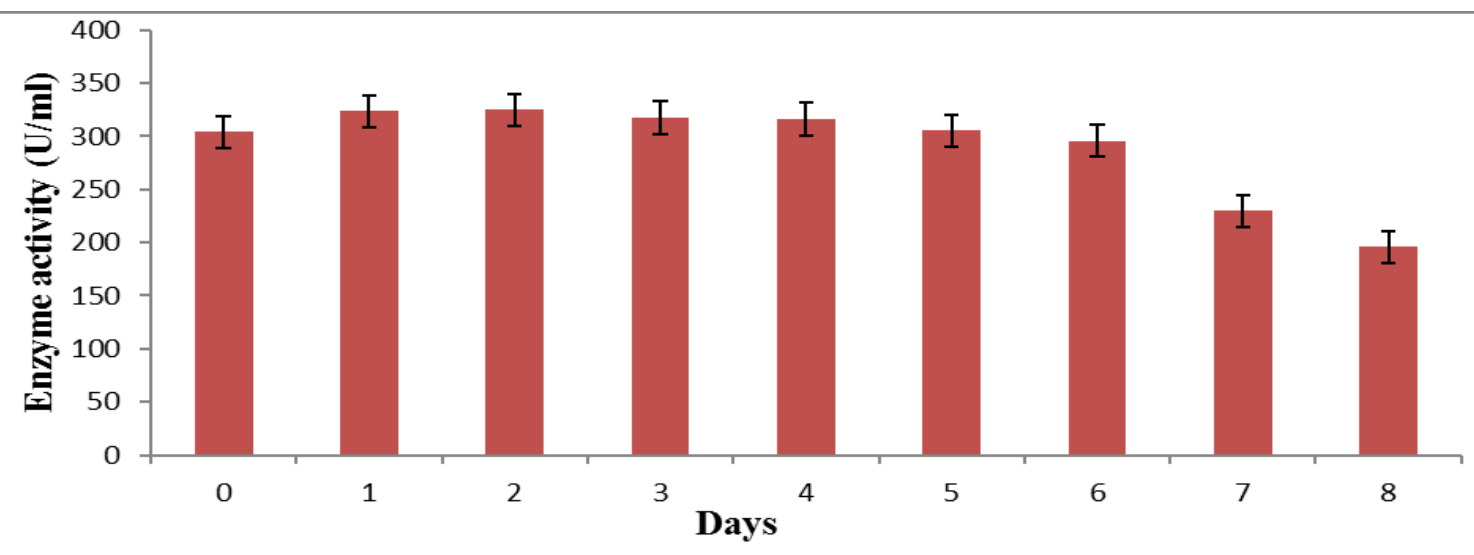

Fig 1: Effect of incubation period on amylase production

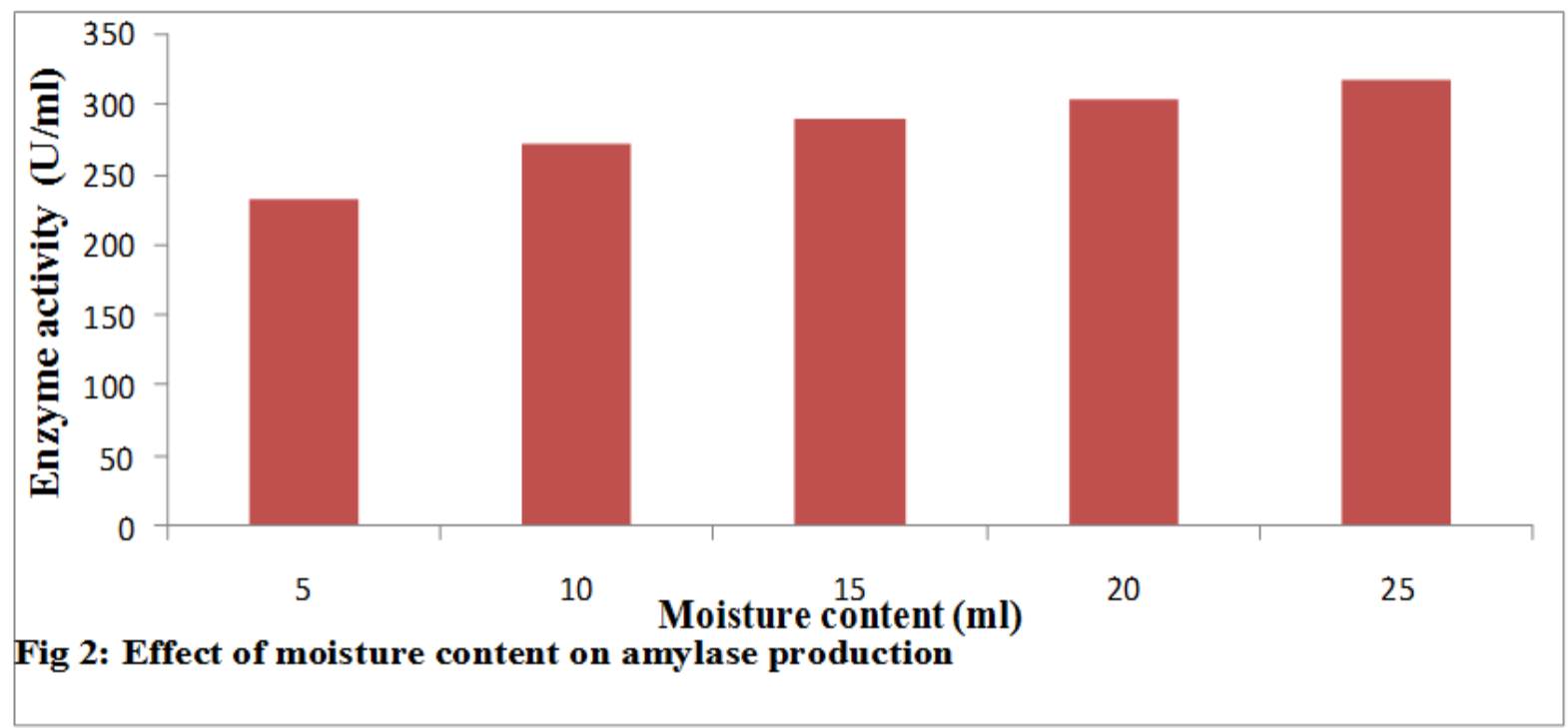




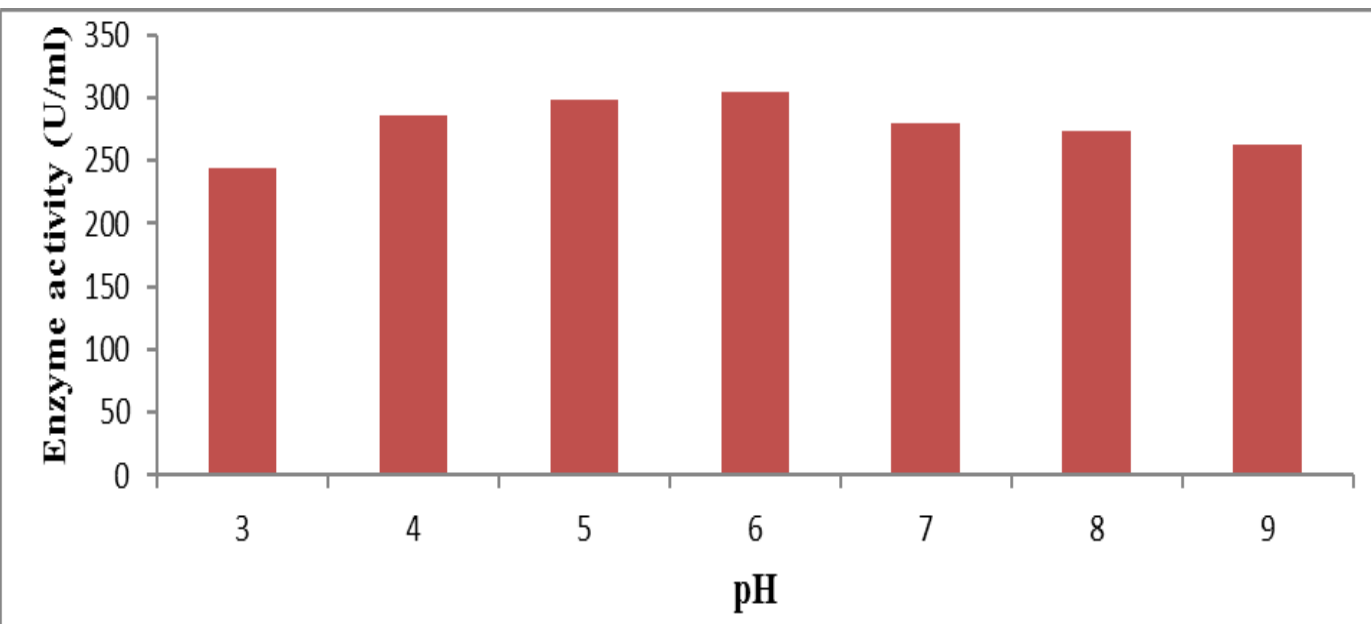

Fig 3: Effect of initial $\mathrm{pH}$ on amylase production

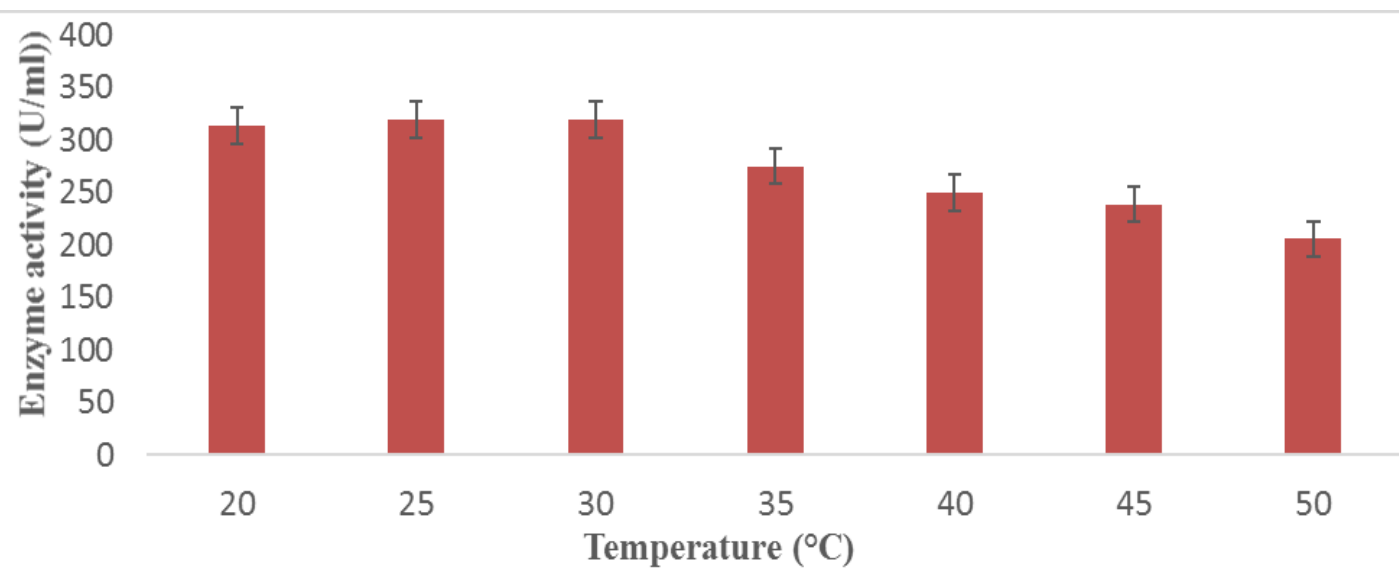

Fig 4: Effect of temperature on amylase production

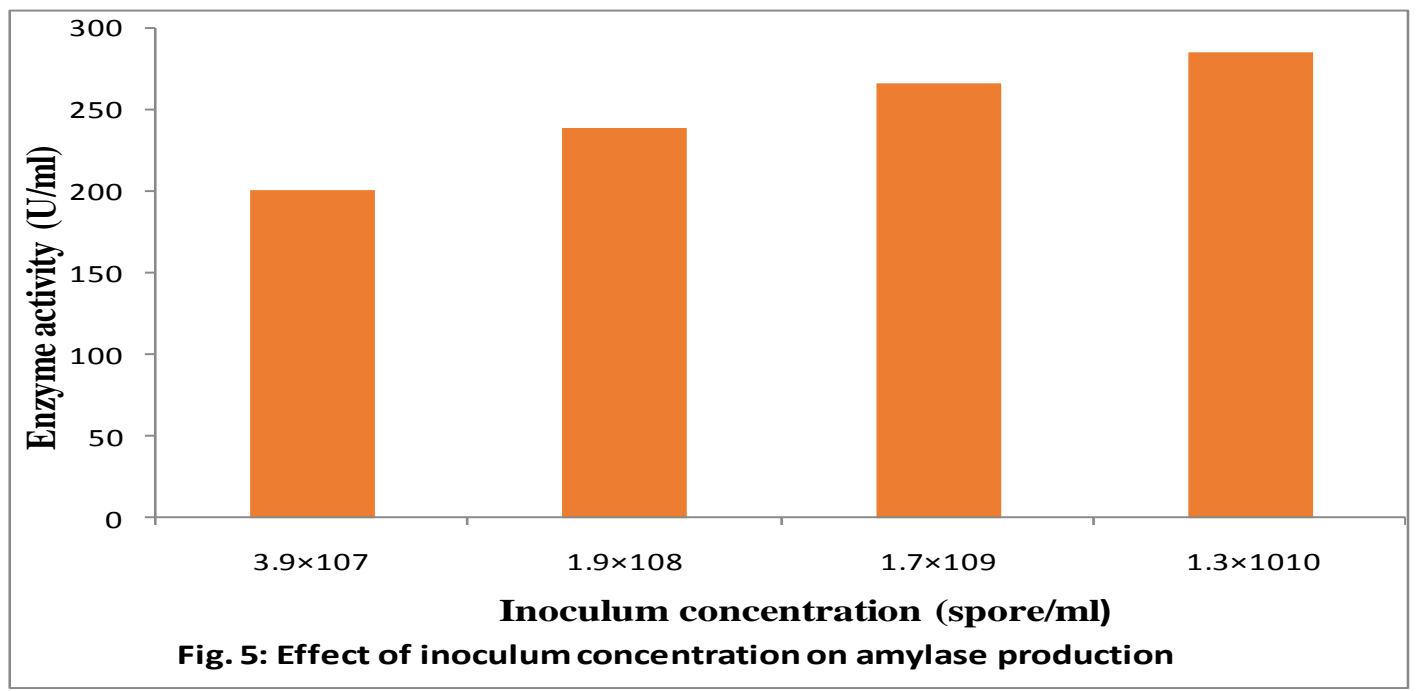




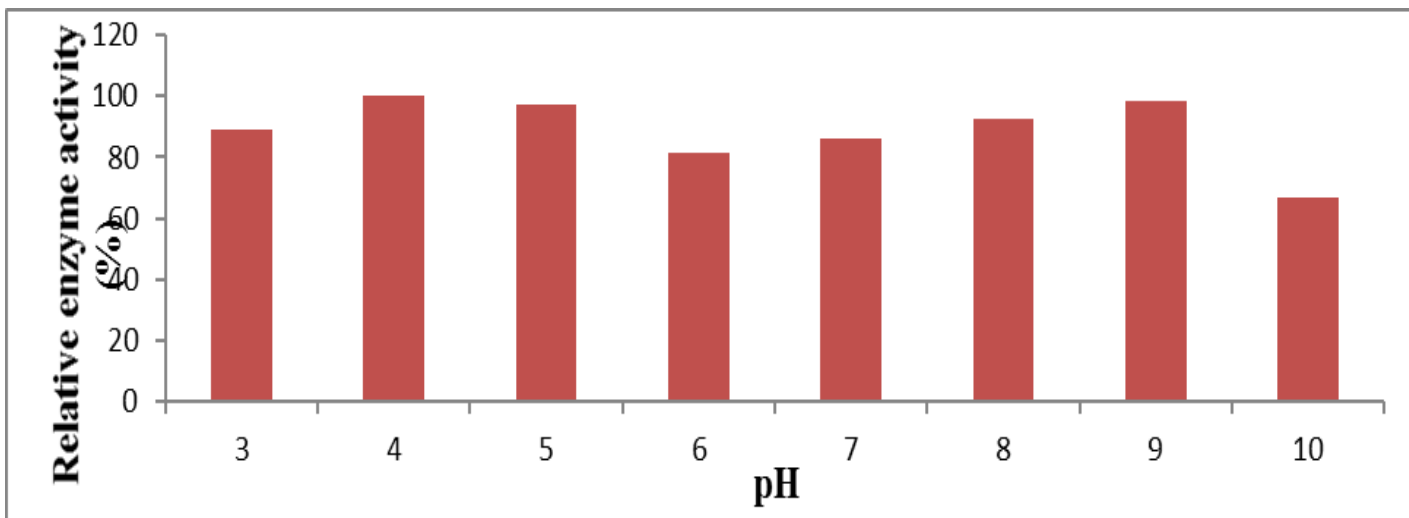

Fig 6: Effect of $\mathrm{pH}$ on partially purified amylase activity

(Each $\mathrm{pH}$ is expressed in relative enzyme activity with the highest taken as 100\%)

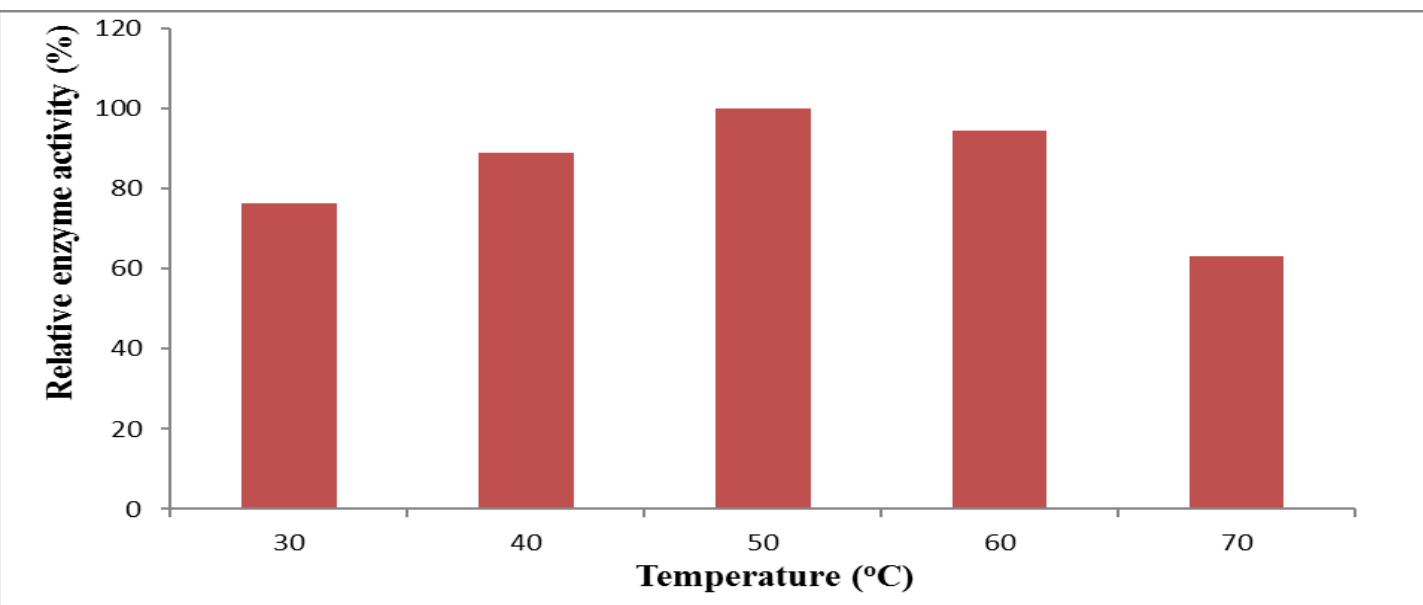

Fig 7: Effect of temperature on partially purified amylase activity

(Each temperature is expressed in relative enzyme activity with the highest taken as $100 \%$ )

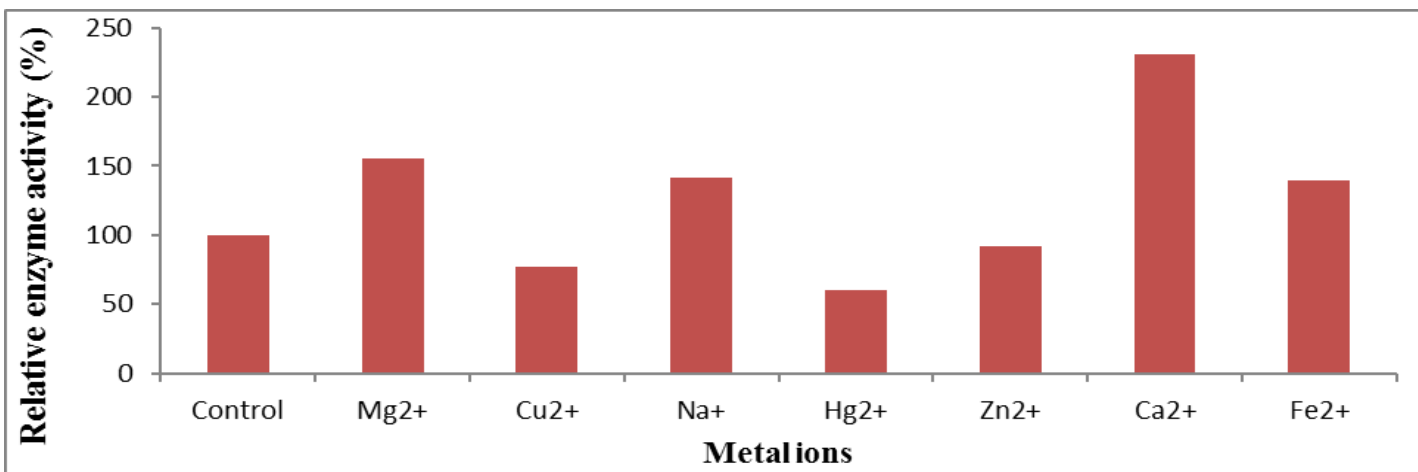

Fig 8: Effect of metal ions on partially purified amylase activity 
The result of this study revealed that wheat bran yielded maximum enzyme production thus was selected as substrate for further studies. This result notably corroborates with the reports of Singh et al., (2014) and Ferreira et al., (2015), who stated that maximum amylase production were observed when wheat bran was used as the substrate under SSF by Aspergillus fumigatus NTCC122 and Rhizopus oryzae respectively. Also, when wheat bran was used as solid substrate there was high production of amylase by the isolate W74 (Tsegaye and Gessesse, 2014). Furthermore, it was reported that wheat bran was the best substrate for the synthesis of amylase by other researchers (Balkan and Ertan, 2007; Singh et al., 2010).

Maximum yield of amylase was observed on the second day $(48 \mathrm{~h})$ of incubation with further increase in the period of fermentation leading to a reduction in the production of amylase. The reduction in yield may be because the culture has entered death phase of growth, reduction of nutrient (Arzumanov et al., 2000), the build-up of by-products and different toxins and also deterioration in the enzyme system (Sikander et al., 2003). This result is in contrast with the reports of Chimata et al., (2010), Farid and Shata (2011) and Puri et al., (2013), where other amylase producing fungi gave maximum yield at a period of 5 days. However, this observation corroborates with the findings of GeorgeOkafor et al., (2013) where a period of $48 \mathrm{~h}$ was enough for Aspergillus oryzae-SR2 to give maximum amylase production in submerged fermentation. When the incubation period was increased, there was a decrease in amylase production. Singh et al., (2012) also reported that Streptomyces sp. MSC702 produced maximum quantity of amylase after an incubation period of $48 \mathrm{~h}$. According to Gupta et al., (2008), the decrease in activity at the later phase of growth probably was because of catabolite repression by glucose which was released from starch hydrolysis. The incubation period differs depending on the enzyme. Short incubation creates room for cheap enzyme production (Somjoy et al., 1995). However, the kind of media used, rate at which microorganism grow on a carbon source and its pattern for enzyme synthesis all affect the incubation time for maximum enzyme production (Grover et al., 2013).

Moisture is very important in the regulation and optimization of solid state fermentation process (Laukevics et al., 1984). The results illustrated that twenty five milliliters $(25 \mathrm{ml})$ of medium to five grams $(5 \mathrm{~g})$ of substrate i.e. ratio $1: 5(83.3 \%)$ was the optimum moisture level. In a related manner, the production of amylase was maximum when moisture content was $80 \%$ under SSF of rice bran using Aspergillus oryzae MTCC 3107 (Puri et al., 2013). Also, in previous studies on the production of extracellular amylases using Thermomyces lanuginosus ATCC 58157 by solid state fermentation (SSF) of wheat bran, it was discovered that yield was highest at 90\% initial moisture content as compared to $83.3 \%$ moisture content in our study (Kunamneni et al., 2005).

Kundu et al., (1984) stated that there were enzyme inhibition and greater diffusion of enzyme from the substrates when the moisture levels were below and above the determined optimal levels respectively. Small quantity of moisture reduces the growth of the organism and the activity of the enzyme and also the level at which the organism access the nutrients, while excess moisture compacts the substrate, obstructs the penetration of oxygen and makes it possible for fast growing bacteria to cause contamination (Laukevics et al., 1984). However, the substrate used affects the optimum moisture level because various types of substrate have different capacities at 
which they hold water (Grover et al., 2013).

Maximum amylase production was obtained at initial $\mathrm{pH}$ value of 6.0 . Results reveal that when the initial $\mathrm{pH}$ of the medium was of value higher than 6.0, there was reduction in amylase production. The $\mathrm{pH}$ of the fermentation medium is the most critical parameter for amylase production process therefore maintenance of the medium $\mathrm{pH}$ is paramount for successful fermentation of amylase. Fungal strains tend to thrive best in acidic medium ranging from 3 to 6 (Fawole and Odunfa, 2003), hence the $\mathrm{pH}$ range of 2 to 6 is frequently utilized for submerged and solid state fermentation (Adham, 2002; Lesuiak et al., 2002). Sivaramakrishnan et al., (2006) also opined that slightly acidic $\mathrm{pH}$ is needed for fungi growth. Our observations are in corroboration with the reports of Zambare (2010), who similarly reported initial pH 6.0 for maximum yield of amylase of 0.198 IU by solid state fermentation of wheat bran using Aspergillus oryzae. Singh et al., (2014), in a study on amylase synthesis and supernatant protein concentration from Aspergillus fumigatus NTCC1222 reported maximum yields at $\mathrm{pH} 6.0(339.1 \mathrm{U} / \mathrm{ml}, 8.1 \mathrm{mg} / \mathrm{ml}$ respectively). Furthermore, Vidya et al., (2012) in their study on the effect of different initial $\mathrm{pH}$ on the synthesis of amylase from Penicillium chrysogenum stated that maximum production was at $\mathrm{pH}$ of 6.0 . Maintenance of the $\mathrm{pH}$ value at the beginning of fermentation is necessary for specific biomass formation (Kareem et al., 2010).

Temperature of $30^{\circ} \mathrm{C}$ gave the highest amylase production from our findings. This result agrees with the reports of Sivaramkrishnan et al., (2007) who stated that maximum amylase production of $15095 \mathrm{U} / \mathrm{gds}$ for fourteen (14) agro industrial residues was achieved at temperature of $30^{\circ} \mathrm{C}$. Temperature for incubation is a very important factor in enzyme production (Seyis and Aksoz, 2003).
Similarly, Nwagu and Okolo (2010) in a study on the synthesis of amylase observed that temperature of $30^{\circ} \mathrm{C}$ was optimum for maximum amylolytic activity of Aspergillus fumigates, which is a thermophilic fungi. Chimata et al., (2010) also reported that amylase production by Aspergillus sp. MK07 was highest when the temperature was $30^{\circ} \mathrm{C}$. Optimal temperature for efficient production of amylase was reported to be $30^{\circ} \mathrm{C}$ (Gupta et al., 2008; Alva et al., 2007) and $30-37^{\circ} \mathrm{C}$ (Ueno et al., 1987, Kundu et al., 1973). According to Simoes et al., (2009), very low and high temperature reduces the synthesis of enzyme due to inhibition of the growth of the organism. Furthermore, when the temperature is low there is membrane solidification while there is damage of the microorganisms by enzyme denaturation which results to low enzyme production when the temperature is high (Willey et al., 2008).

Maximum amylase secretion (284.69 U/ml) was obtained when the inoculum size was $1.30 \times 10^{10}$ spores $/ \mathrm{ml}$. Enzyme production reduced as inoculum size increased. This may be as a result of the limitation of nutrients at higher inoculum size (Tsegaye and Gessesse, 2014). Our results corroborated with the findings of Esfahanibolandbalaie et al., (2008), who observed that increase in inoculum size yielded a gradual decrease in the production of amylase by Aspergillus oryzae. This reveals that there is reduction of the surface area available in the medium in the presence of high inoculum; thus, affecting the amount of oxygen needed by the organism to carryout fermentation (George-Okafor et al., 2013). Previous reports showed that high fungal load adversely affected enzyme production (Acharya et al., 2008; Chimata et al., 2010).

Our result indicated that maximum enzyme secretion was obtained after 2 days ( $48 \mathrm{~h}$ ) of cultivation with optimized SSF conditions. 
The crude enzyme was partially purified using different fractions of ammonium sulphate. Eighty percent $(80 \%)$ fraction gave highest amylase activity and was used for characterization studies. The purification by ammonium sulphate precipitation (80\% saturation) gave 3.77 purification fold and a yield of $90.53 \%$. The specific activity of the purified amylase was $36.65 \mathrm{U} / \mathrm{mg}$ while the crude enzyme had a specific activity of 9.71 $\mathrm{U} / \mathrm{mg}$. A thermo stable amylase from novel thermophilic actinobacteria Streptomyces $s p$. MSC702 which had 2.98 fold purification and a yield of $56.58 \%$ by ammonium sulphate precipitation (40-60\% saturation), was reported by Singh et al., (2014). Fifty-five percent $(55 \%)$ recovery of amylase from Thermobifida fusca NTU22 having a purification fold of 1.3 by ammonium sulphate precipitation was reported by Yang and Liu (2004). Purification fold of 1.3 and $4.29 \%$ yield of amylase produced by Geobacillus LH8 strain was obtained (Mollania et al., 2010). In comparison to the previous reports, a higher purification fold and yield were obtained in this study.

The influence of $\mathrm{pH}$ on the activity of the partially purified amylase was studied. Highest amylase activity was observed at $\mathrm{pH}$ 4.0 when the activity of the enzyme was measured at different $\mathrm{pH}$ (3.0-10.0). Enzyme activity declined between $\mathrm{pH} 5.0$ to 8.0 and rose again at $\mathrm{pH}$ 9.0, retaining $98.18 \%$ activity. At $\mathrm{pH} 10.0$, amylase activity was least with $66.85 \%$ activity retained. Amylases which maintain high activity at low $\mathrm{pH}$ are very relevant in industrial processes (Sajedi $e t$ al., 2005). Natural starch slurry has $\mathrm{pH}$ of 4.5 and its pretreatment in such extreme condition requires using an enzyme which can withstand low pH (Sivaramakrishnan et al., 2006). Furthermore, using amylase that perform very well at lower $\mathrm{pH}$ value helps in reducing the formation of certain by-products which are formed at high $\mathrm{pH}$ (Goyal et al.,
2005). Our result is in corroboration with the reports of Singh et al., (2014) who recorded that that partially purified amylase from Streptomyces sp MSC702 had highest activity at pH 5.0. Similarly, Ojo and Ajele (2011) obtained purified amylase which had highest activity at $\mathrm{pH} 5.0$ from cassava peels.

The effect of temperature in other to know the thermo-stability of the partially purified amylase was carried out. Maximum amylase activity was achieved at $50^{\circ} \mathrm{C}$ when enzyme activity was measured at various temperatures $\left(30^{\circ} \mathrm{C}-70^{\circ} \mathrm{C}\right)$. Enzyme activity showed gradual increase from $30^{\circ} \mathrm{C}$ to $50^{\circ} \mathrm{C}$ after which there was a decline from $60^{\circ} \mathrm{C}$ to $70^{\circ} \mathrm{C}$, which was the least with $63.12 \%$ activity retained. Our result revealed that the partially purified amylase is thermo tolerant in nature, hence having great potential compatibility with conventional industrial processes. In a similar manner, Sexena and Singh (2011) reported that partially purified amylase from Bacillus sp. recorded highest activity at $50^{\circ} \mathrm{C}$. Singh $e t$ al., (2014) reported a thermo stable partially purified amylase from Aspergillus fumigatus NTCC1222 which had maximum activity at $55^{\circ} \mathrm{C}$. A study by Doss and Anand (2012) reported that partially purified amylase by Aspergillus flavipes showed maximum activity at temperature of $60^{\circ} \mathrm{C}$ to $70^{\circ} \mathrm{C}$ while partially purified amylase gotten from cassava peels had optimum activity at $60^{\circ} \mathrm{C}$ (Ojo and Ajele, 2011).

The effect of some metal ions $\left(\mathrm{Mg}^{2+}, \mathrm{Cu}^{2+}\right.$, $\mathrm{Na}^{+}, \mathrm{Hg}^{2+}, \mathrm{Zn}^{2+}, \mathrm{Fe}^{2+}$ and $\mathrm{Ca}^{2+}$ ) on the activity of the partially purified amylase was studied. Our result indicated that the metal ions; $\mathrm{Hg}^{2+}$, $\mathrm{Cu}^{2+}$ and $\mathrm{Zn}^{2+}$ inhibited amylase activity with $\mathrm{Hg}^{2+}$ being the most potent inhibitor by up to $39.66 \%$. Inhibition of $\mathrm{Hg}^{2+}$ is indicated by residues of indole amino acid being present in the enzyme (Chakraborty et al., 2012). Syed et al., (2009) and Chakraborty et al., (2009) also reported the inhibition of amylases from 
Streptomyces sp. D1 and Streptomyces gulbargensis by $\mathrm{Hg}^{2+}$ ion. The inhibition of amylase activity by $\mathrm{Cu}^{2+}$ ion was also reported by Ojo and Ajele (2011). Amylase activity inhibition as a result of the presence of $\mathrm{Zn}^{2+}$ ions shows the nature of the thermo stability of the enzyme (Gessesse and Mamo, 1999) while the inhibition as a result of the presence of $\mathrm{Cu}^{2+}$ ions reflects the competition between the exogenous cations and the protein associated cations (Singh et al., 2014). The presence of $\mathrm{Mg}^{2+}, \mathrm{Na}^{+}, \mathrm{Fe}^{2+}$ and $\mathrm{Ca}^{2+}$ increased the activity of the enzyme with $\mathrm{Ca}^{2+}$ having the highest activity. In a similar manner, Adejuwon (2011) and Sexena and Singh (2011) reported that the presence of $\mathrm{Ca}^{2+}, \mathrm{Na}^{+}$and $\mathrm{Mg}^{2+}$ ions enhanced the activity of amylase from Penicillium species and Bacillus species respectively. This result is also supported by reports of Burhan et al., (2003) where the presence of $\mathrm{Ca}^{2+}$ ion enhanced the activity of amylase from Bacillus sp. ANT-6. $\mathrm{Ca}^{2+}$ ion is known for its stabilizing effects on the thermo stability of amylases gotten from various microorganisms (Sivaramakrishnan et al., 2006).

In conclusion the four agricultural waste products (wheat bran, cassava peels, groundnut husk and rice bran) studied in this work showed potentials for amylase production. The study revealed that wheat bran gave the highest amylase production followed by cassava peels, groundnut and rice bran. These substrates are readily available in large quantities in Nigeria and can be of benefit in low cost industrial production of amylase. This study also revealed that amylase producing fungi can be gotten from decayed agricultural wastes. The fungal isolate used for this work was identified as Aspergillus niger DTO: 133-H5 (KX786646) using its $18 \mathrm{~S}$ rRNA sequence analysis.

Wheat bran served as an inexpensive and under-utilized agricultural waste product, supported the growth of Aspergillus niger DTO: 133-H5 (KX786646) and the production of amylase under the fermentation parameters investigated. Optimal SSF conditions which favoured the production of amylase were; fermentation period of $48 \mathrm{~h}$, initial $\mathrm{pH} 6.0$, initial temperature of $30^{\circ} \mathrm{C}$, substrate to moisture content ratio of $1: 5$ and inoculum size of $1.30 \times 10^{10} \mathrm{cells} / \mathrm{ml}$.

The partially purified amylase obtained was found to be thermo-stable and acid stable with highest activity observed at $50^{\circ} \mathrm{C}$ and $\mathrm{pH} 4.0$. The enzyme was active in the presence of $\mathrm{Ca}^{2+}, \mathrm{Na}^{+}, \mathrm{Mg}^{2+}$ and $\mathrm{Fe}^{2+}$ ions while its activity was inhibited in the presence of $\mathrm{Hg}^{2+}$, $\mathrm{Cu}^{2+}$ and $\mathrm{Zn}^{2+}$ ions. This study is therefore, relevant with regard to re-utilization of agricultural waste products and conversion of waste to wealth as well as reducing the level of pollution caused by these agricultural wastes.

The results obtained are significant as they have shown that the enzyme is thermo-active and active under slightly acidic conditions thus suitable for industrial processes which require high temperature and low $\mathrm{pH}$ such as textile wet processing, pretreatment of nongelatinized starch to gelatinized starch, soap and detergent production.

\section{References}

Abu, E.A., Ado, S.A. and James, D.B. 2005. Raw starch degrading amylase production by mixed culture of Aspergillus niger and Saccharomyces cerevisae grown on Sorghum pomace. Afr. J. Biotechnol., 4: 785-790.

Acharya, P.B., Acharya, D.K. and Modi, H.A. 2008. Optimization for cellulose production by Aspergillus niger using saw dust as substrate. African $J$. Biotechnol., 7: 4147-4152.

Adejuwon, A.O. 2011. Synthetic production 
of amylase from Penicillium species isolated from apple fruit. World Appl. Sci. J., 13(3): 415-418.

Adham, N.Z. 2002. Attempts at improving citric acid fermentation by Aspergillus niger in beet-molasses medium. Biores. Technol., 84(1): 97-100.

Alva, S., Anupama, J., Savla, J., Chiu, Y.Y., Vyshali, P., Shruti, M., Yogeetha, B.S., Bhavya, D., Purvi, J., Ruchi, K., Kumudini, B.S. and Varalakshmi, K.N. 2007. Production and characterization of fungal amylase enzyme isolated from Aspergillus sp. JGI 12 in solid state culture. African J. Biotechnol., 6(5): 576-581.

Aneja, K.R. 2003. Experiments in Microbiology plant pathology and biotechnology. New Age International Limited, publishers, New Delhi. 607.

Arguelles, A.M., Rojas, G.M., Gonzalez, V.G. and Torres, F.E. 1995. Production of three pectinolytic activities produced by Aspergillus niger in submerge and solid state fermentation. Appl. Microbial. Biotechnol., 43: 808-814.

Arzumanov, T.E., Schishkanova, N.V., and Finogenova, T.V. 2000. Biosynthesis of citric acid by Yarrowia lipolytica Repeat- batch Culture on Ethanol. Appl. Microbiol. Biotechnol., 53: 525-529.

Balkan, B. and Ertan, F. 2007. Production of $\alpha$-amylase from Penicillium chrysogenum under solid-state fermentation by using some agricultural by-products. Food Technol. Biotechnol., 45(4): 439-442.

Behera, B.C., Parida, S., Dutta, S.K. and Thatoi, H.N. 2014. Isolation and identification of cellulose degrading bacteria from mangrove soil of Mahanadi River Delta and their cellulose production ability. American J. Microbiol. Res., 2(1): 41-46.

Burhan, A., Nisa, U., Gokhan, C., Omer, C.,
Ashabil, A. and Osman, G. 2003. Enzymatic properties of a novel thermostable thermophilic, alkaline and chelator resistant amylase from an alkaliphilic Bacillus sp. isolate ANT-6. Process Biochem., 38: 1397-1403.

Chakraborty, S., Khopade, A., Kokare, C., Mahadik, K. and Chopade, B. 2009. Isolation and characterization of novel $\alpha$-amylase frommarine Streptomyces sp.D1. J. Mol. Catalysis B: Enzymatic, 58(1-4): 17-23.

Chakraborty, S., Raut, G., Khopade, A., Mahadik, K. and Kokare, C. 2012. Study on calcium ion independent $\alpha$ amylase from haloalkaliphilic marine Streptomyces strain A3. Indian J. Biotechnol., 11(4): 427-437.

Chimata, M.K., Sasidhar, P. and Challa, S. 2010. Production of extracellular amylase from agricultural residues by a newly isolated Aspergillus species in solid state fermentation. African $J$. Biotechnol., 9(32): 5163-5169.

Doss, A. and Anand, S.P. 2012. Purification and characterization of extracellular amylolytic enzyme from Aspergillus species. African J. Biotechnol., 11(83): 14941- 14945

Esfahanibolandbalaie, Z., Rostami, K. and Mirdamadi, S.S. 2008. Some studies of alpha amylase production using Aspergillus oryzae. Pak. J. Biol. Sci., 11: 2553-2559.

Farid, M.A.F. and Shata, H.M.A.H. 2011. Amylase production from Aspergillus oryzae LSI by solid state fermentation and its use for the hydrolysis of wheat flour. Iranian J. Biotechnol., 9: 267274.

Fawole, O.B. and Odunfa, S.A. 2003. Some factors affecting production of pectin enzymes by Aspergillus niger. Int. Biodeterioration and Biodegradation, 53(4): 223-227.

George-Okafor, U.O., Tasie, F.O. and 
Anyamene, N.C. 2013. Studies on low cost substrates and other cultural conditions for optimal amylase yield from Aspergillus oryzae SR2. American J. Food Technol.

Gessesse, A. and Mamo, G. 1999. High-level xylanase production by an alkaliphilic Bacillus sp. by using solid-state fermentation. Enzyme and Microbial Technol., 25(1-2): 68-72.

Gomes, E., Souza, S.R., Grandi, R.P. and Silva, E.D. 2005. Production of thermostable glucoamylase by newly isolated Aspergillus flavus A.1.1 and Thermomyces lanuginosus A 13.37. Braz. J. Microbiol., 36: 75-82.

Goyal, N., Gupta, J.K. and Soni, S.K. 2005. A novel raw starch digesting thermostable $\alpha$ - amylase from Bacillus sp. I-3 and its use in the direct hydrolysis of raw potato starch. Enzyme and Microbial Technol., 37(7): 723-734.

Grover, A., Maninder, A. and Sarao, L.K. 2013. Production of fungal amylase and cellulase enzymes via solid state fermentation using Aspergillus oryzae and Trichoderma reesei. Int. J. Advancements in Res. Technol., 2: 8.

Gupta, A., Gupta, V.K., Modi, D.R. and Yadava, L.P. 2008. Production and characterization of alpha amylase from Aspergillus niger. Biotechnol., 7(3): 551-556.

Kareem, S.O., Akpan, I. and Alebiowu, O.O. 2010. Production of citric acid by Aspergillus niger using pineapple waste. Malaysian J. Microbiol., 6(2): 161-165.

Kathiresan, K. and Manivannan, S. 2006. $\alpha$ Amylase production by Penicillium fellutanum isolated from mangrove rhizosphere soil. African J. Biotech., 5(10): 829-832.

Kirankumar, V., Ravi, S. N., Shailaja, R., Saritha, K., Siddhartha, E., Ramya, S., Giridhar, D. and Sahaja, R.V. 2011.
Purification and Characterization of $\alpha$ Amylase Produced by Aspergillus niger using Banana Peels. J. Cell and Tissue Res., 11(2): 2775- 2780.

Kheng, P.P. and Omar, C.I. 2005. Xylanase production by local fungal isolate Aspergillus niger USM AII via solid state fermentation using palm kernel cake as substrate. J. Sci. Technol., 27(2): 325-336.

Kunamneni, A., Perumal, K. and Singh, S. 2005. Amylase production in solid state fermentation by the thermophilic fungus Thermomyces lanuginosus. J. Biosci. Bioeng., 100(2): 168-171.

Kundu, A.B., Ghosh, B.S., Ghosh, B.L. and Ghose, S.N. 1983. Annual report on fermentation process. J. Fermentation Technol., 7: 213-356.

Laukevics, J.J., Aspite, A.F., Veistures, V.E. and Tengerdy, R.P. 1984. Solid state fermentation of wheat straw to fungal protein. Biotechnol. Bioengi., 26: 14651474.

Lowry, O.H., Rosebrough, N.J., Farr, A.L. and Randall, R.J. 1951. Protein measurement with the Folin Phenol reagent. J. Biol. Chem., 193(1): 265275.

Maarel, V.M.J.E.C., Veen, V.B., Uitdehaag, J.C.M., Leemhuis, H. and Dijkhuizen, Properties and applications of starchconverting enzymes of the a-amylase family. J. Biotechnol., 94: 137-155.

Miller, G.L. 1959. Use of dinitrosalicylic acid reagent for determination of reducing sugar. Anal. Chem., 31: 426-429.

Mollania, N., Khajeh, K., Hosseinkhani, S. and Dabirmanesh, B. 2010. Purification and characterization of a thermostable phytate resistant $\alpha$-amylase from Geobacillus sp. LH8. Int. J. Biol. Macromol., 46(1): 27-36.

Nwagu, T.N. and Okolo, B.N. 2010. Growth profile and amylase hydrolytic activity of a thermophilic fungi Aspergillus 
fumigatus isolated from soil. Asian $J$. Biotechnol., 3(1): 46-57.

Ojo, O.O. and Ajele, J.O. 2011. Isolation Purification Characterization and the Possible Involvement of Histidine and Cysteine in the Catalytic Mechanism of Beta-amylase Sourced from Cassava (Manihot esculenta Crantz) Peel. Pak. J. Nutrition, 10(9): 823-830.

Okolo, B.N., Ire, F.S, Ezeogu, L.I., Anyanwu, C.U. and Odibo, F.J.C. 2000. Purification and some properties of a novel raw starch digesting amylase from Aspergillus carbonarius. J. Sci. Food and Agri., 81: 329 - 336.

Puri, S., Arora, M. and Sarao, L. 2013. Production and optimization of amylase and glucoamylase using Aspergillus oryzae under solid state fermentation. Int. J. Res. Pure and Appl. Microbiol., 3(3): 83-88.

Sajedi, R.H., Naderi, M.H. and Khajeh, K. 2005. A Caindependent $\alpha$-amylase that is active and stable at low $\mathrm{pH}$ from the Bacillus sp.KR-8104. Enzyme and Microbial Technol., 36(5-6): 666-671.

Sexena, R. and Singh, R. 2011. Amylase production by solid-state fermentation of agro- industrial wastes using Bacillus sp. Brazilian J. Microbiol., 42: 13341342.

Sikander, A., Asad, U.R., Amna, E., Ikram, U.H. and Javed, I. 2003. Effect of vegetative inoculum of submerged citric acid fermentation by Aspergillus niger. Pak. J. Biol. Sci., 6(4): 334-335.

Sindhu, R, Suprabha, G, N. and Shashidhar, S. 2009. Optimization of process parameters for the production of alpha amylase from Penicillium janthinellum (NCIM 4960) under solid state fermentation. Afr. J. Microb. Res., 3(9): 498-503.

Singh, R., Kapoor, V. and Kumar, V. 2012. Utilization of Agro-industrial wastes for the simultaneous production of amylase and xylanase by thermophilic actinomycetes. Brazilian J. Microbiol., 1545-1552.

Singh, R.K., Mishra, S.K. and Kumar, N. 2010. Optimization of $\alpha$-amylase production on agriculture by-product by Bacillus cereus MTCC 1305 using solid state fermentation. Res. J. Pharma., Biol. Chem. Sci., 1(4): 867-876.

Singh, S., Singh, S., Bali, V., Sharma, L. and Mangla, J. 2014. Production of Fungal Amylases Using Cheap, Readily Available Agro residues, for Potential Application in Textile Industry. BioMed Res. Int., 9.

Sivaramakrishnan, S., Gangadharan, D., Nampoorthiri, K., Soccol, C. and Pandey, A. 2006. Alpha-amylases from microbial sources-An overview on recent development. Food Technol. Biotechnol., 44: 173-184.

Sivaramakrishnan, S., Gangadharan, D., Nampoothiri, K.M., Soccol, C.R. and Pandey, A. 2007. Alpha amylase production by Aspergillus oryzae employing solid-state fermentation. $J$. Scientific and Industrial Res., 66: 621626.

Sodhi, H.K., Sharma, K., Gupta, J.K. and Soni, S.K. 2005. Production of a thermostable alpha amylase from Bacillus sp. PS-7 by solid state fermentation and its synergistic use in the hydrolysis of malt starch for alcohol production. Process. Biochem., 40: 525534.

Sonjoy, S., Bill, B. and Houston, K.H. 1995. Cellular activity of Trichoderma ressei (RUT- C30) on municipal solid waste. Appl. Biochem. Biotechnol. J., 15: 145153.

Tsegaye, K.N. and Gessesse, A. 2014. Amylase production under solid state fermentation by a bacterial isolate W74. African J. Biotechnol., 13(21): 21452153. 
Ueno, S., Miyama, M., Ohashi, Y., Izumiya, M. and Kusaka, I. 1987. Secretory enzyme production and conidiation of Aspergillus oryzae in submerged liquid culture. Appl. Microbiol. Biotechnol. J., 26: 273-276.

Vidya, B., Gomathi, D., Kalaiselvi, M., Ravikumar, G. and Uma, C. 2012. Production and optimization of amylase from Penicillium chrysogenum under submerged fermentation. World $J$.
Pharma. Res., 1(2): 1116-1125.

Yang, C.H. and Liu, W.H. 2004. Purification and properties of a maltotrioseproducing $\alpha-$ amylase from Thermobifida fusca. Enzyme and Microbial Technol., 35(2-3): 254-260.

Zambare, V. 2010. Solid state fermentation of Aspergillus oryzae for glucoamylase production on agro residues. Int. J. Life Sci., 4: 16-25.

\section{How to cite this article:}

Ire, F.S., O.C. Eruteya and Amaechi, V. 2017. Optimization of Culture Conditions Using OneFactor-at-Time Methodology and Partial Purification of Amylase from Aspergillus niger of DTO: H5 Under Solid State Fermentation. Int.J.Curr.Microbiol.App.Sci. 6(5): 307-325. doi: http://dx.doi.org/10.20546/ijcmas.2017.605.035 